\title{
ENVIRONMENTAL AND CHEMICAL STUDIES ON SOME EXTRACTED ACTIVE COMPONENTS OF BARLEY
}

Hashem, A. I. ${ }^{(1)}$; Abd El-Latif, Bothaina. M. ${ }^{(2)}$ and Shaban, Hala, H. ${ }^{(2)}$ 1) Faculty of Science, Ain Shams University 2) Food Tech. Research Institute, Agriculture Research Center.

\begin{abstract}
$\beta$-Glucan is the effective naturally occurring compound that exists in the grains of Hordeum vulgaris $L$ (barley). $\beta$-Glucan is a rich fiber fraction found as glucose polymer in the endosperm cell walls of barley and usually at a level of 2-8 of grain weight. Extraction treatment affected the yield of barley $\beta$-glucan (BBG) fiber fraction, and $\beta$-glucan recovery efficiency $(P \leq 0.05)$. Its chemical composition and physical properties make it a functional ingredient which can be used in different healthy food products. Thus its health benefits are linked to its high viscosity and its nature as a soluble dietary fiber.

In this investigation different treatments to extract $\beta$-glucan from barley are examined. Functional properties of extracted $\beta$-glucan gum as solubility, viscosity, foaming properties, water hydration and fat absorption capacities are determined. These characteristics make it suitable as a fat replacer in food products. Since cake needs high fat to make, it was chosen and prepared by utilizing $\beta$-glucan as fat replacer with different levels, its physical and chemical properties are examined.
\end{abstract}

Keywords: $\beta$-glucan, grain weight, functional ingredients, fat replacer. 
J. Environ. Sci.

Institute of Environmental Studies and Research - Ain Shams University

\section{INTRODUCTION}

Barley, Hordeum vulgaris $L$, is an ancient crop plant, and is also one of the world's most cultivated cereal crops. World production in 2000/2003 has been evaluated at approximately 134 million metric tons. Europe is one of the leading barley producers (51.659 Mt) followed by the Former Soviet Union (25.013 Mt), and Canada (13.172 Mt). In the UK barley has a particular importance as being the second most important crop, with approximately 6.2 million metric tons produced in 2002 (HGCA 2003). This year the United States Department of Agriculture (USDA) estimates that the World Barley Production 2015/2016 will be 144.81 million metric tons, around 0.2 million tons more than the previous month's production. Barley Production last year was 141.16 million tons. This year's 144.81 estimated million tons could represent an increase of 3.65 million tons or a $2.59 \%$ in barley production around the globe (USDA 2015).

Barley, which is a source of dietary fiber, $\beta$-glucan, and antioxidants, has been used as a staple food in several areas of the world for centuries (Ames et al., 2006 and Mahdi et al., 2008).

As a food source, barley contains starch (65-68\%), protein (10-17\%), bglucan (4-9\%), lipids (2-3\%) and minerals (1.5-2.5\%). These percentages vary depending on species, crop characteristics and soil environmental conditions (Quinde-Axtell and Baik, 2006).

$\beta$-Glucan is a trivial name for the glucose polymer found in the endosperm cell walls of barley and oats, and it consists of linear unbranched 
polysaccharides of linked $\beta-(1 \rightarrow 3)$ - and $\beta-(1 \rightarrow 4)-D$-glucopyranose units in a non-repeating but nonrandom order.

The extraction methodologies for barley and oat $\beta$-glucan were developed by Wood et al., (1977, 1978), who assessed particle size, temperature, $\mathrm{pH}$ and ionic strength on $\beta$-glucan yield at laboratory scale. These authors prepared an oat gum containing 78\% $\beta$-glucan from oat bran at the pilot plant scale using hot alcohol deactivated oat bran (75\% ethanol /4 hours) and a sodium carbonate extraction at $\mathrm{pH} 10$ (Wood et al., 1989).

The temperature and $\mathrm{pH}$ of extraction process also affects the recovery of $\beta$-glucan. Temelli (1997) illustrated that $\beta$-glucan content increased with temperature, but not $\mathrm{pH}$. Burkus and Temelli (1998) further evaluated the effect of extraction conditions upon yield, composition, and viscosity stability of barley gum from regular barley (Condor) and a waxy cultivar blend. 'Symons and Brennan (2004a) examining extraction procedures have also shown that extraction with thermo stable alpha-amylase yielded the purest $\beta$ glucan fraction.

$\beta$-glucan is used recently for substituting fat in foods and reducing the overall fat and energy intakes. These beneficial effects have been attributed to their gelling and viscosity increasing properties. The Food and Drug Administration in the U.S.A. has allowed a health claim reducing the risks associated with coronary heart diseases on food labels containing soluble $\beta$ glucan obtained from barley (Anon 2006). 
$\beta$-glucan is the effectiveness compound of barley for healthy food products and medicinal uses, thus it is a soluble dietary fiber. The studies related to barley beta glucan were very few so the estimation and properties of beta glucan extracted from barley was tested in this investigation.

This investigation aims at studying the properties of $\beta$-glucan extracted from barley.

\section{MATERIALS AND METHODS}

Hull less barley grains were obtained from Crops Research Institute, Agriculture Research Center, Giza, Egypt. All Chemicals used in this study were of analytical grade

\section{Preparation of barley flour and bran:}

Hull- less barley (naked) was moistened to $14 \%$ moisture for 24 hours and then milled by hammer mill to whole barley flour. Portion of this stayed as it is, and the other portion of flour was sieved through $0.5 \mathrm{~mm}$ sieve to obtain barley bran.

\section{Analytical procedures of raw materials and extracted $\beta$-glucan:}

Moisture, ash, starch, crude protein $(\mathrm{N} \times 6.25)$, crude fiber and ether extract were determined according to the standard methods described by AACC (2010). Total carbohydrates were calculated by difference. Minerals content were determined according to the method described by Jackson (1976) using Atomic Absorption Spectrophotometer (3100). $\beta$-glucan was determined enzymatically according to the method described by Carr et al (1990). Total dietary fiber (TDF), insoluble dietary fiber (IDF) was determined according to the method described by Prosky et al. $(1985,1988)$. 


\section{Extraction of $\beta$-glucan:}

Extraction of $\beta$-glucan from cereals (barley bran or whole barley flour) is a challenge, as it involves at least three stages:

(1)Pre-treatment of raw material, (2) Extraction of $\beta$-glucans and (3) purification/isolation step.

Pre-treatment stage can pursue different objectives: first, to deactivate the endogenous enzymes ( $\beta$-glucanases) responsible for the depolymerization of $\beta$-glucans. A second purpose is to facilitate the later extraction stage, increasing the overall yield of the process. In this case physical treatments, such as sonicating, could be considered. And finally a third group of pretreatments include milling processes: special milling of the barley can be done in order to produce milling fractions enriched in $\beta$-glucans (bran), increasing the amount of $\beta$-glucans extracted. All pre-treatments enhance the performance of the $\beta$-glucan extraction process.

Extraction of $\beta$-glucan from barley bran was carried out according to three methods described by

1- Water extraction (Benito et al. (2009)

2- Aqueous-alkaline extraction (Wood et al. 1978, Wood et al., 1989, Temelli 1997)

3- Enzymatic extraction (Bbatty (1993)

(1). Water extraction: this method involves the following steps:

1. Endogenous enzyme deactivation by the use of ethanol as previous step to the extraction. Barley bran sample was suspended in ethanol $(80 \% \mathrm{v} / \mathrm{v})$ and boiled under reflux for two hours with continuous stirring. After the treatment, the barley bran and the ethanol were separated by filtration. 
Barley bran was dried at $60^{\circ} \mathrm{C}$ and, subsequently, extraction process was carried out, according the procedure described in section 2 .

\section{Batch procedure for extraction of $\beta$-glucans:}

Extraction was carried out in a $1 \mathrm{~L}$ jacked vessel. In each experiment, $25 \mathrm{~g}$ of barley bran were mixed vigorously (500rpm) with $200 \mathrm{ml}$ deionized water for 3 hours at $55^{\circ} \mathrm{C}$. After the extraction, the mixture was centrifuged for 10 minutes at $5000 \mathrm{rpm}$. Solid material was discarded, while liquid extract was kept at $4^{\circ} \mathrm{C}$. All the extraction experiments were carried out in duplicate. $\beta$ Glucan precipitation was done by adding an equal volume of ethanol (96\%, $\mathrm{v} / \mathrm{v})$ to the liquid extract. The white solid obtained was separated from liquid by vacuum filtration, and set at $60^{\circ} \mathrm{C}$ overnight. Once dried, gum was milled and kept in a sealed glass tube until the moment of being analysed.

\section{(2). Aqueous-Alkaline extraction: In this method, the following procedure was followed:}

Water $(500 \mathrm{ml})$ was added to barley bran $(50 \mathrm{~g})$, and the suspension was immediately adjusted at $\mathrm{pH} 7$ with sodium carbonate $(20 \% \mathrm{w} / \mathrm{v})$ and stirred vigorously for $0.5 \mathrm{hr}$ at $45^{\circ} \mathrm{C}$. The mixture was centrifuged (15 min at 15,000 $\times \mathrm{g}, 4^{\circ} \mathrm{C}$ ), the residue retailed for further extraction, and the cooled supernatant adjusted to $\mathrm{PH} 4.5$ with $2 \mathrm{M}-\mathrm{HCl}$ and centrifuged $(20 \mathrm{~min}$ at $\left.21,000 \times \mathrm{g}, 4^{\circ} \mathrm{C}\right)$. This residue was discarded and the cold supernatant made $50 \%$ with respect to 2-propanol (IPA), which was added slowly with vigorous stirring. The precipitate was allowed to settle overnight, collected by centrifugation, resuspended in (IPA) and the rubbery pellet disintegrated in a Vertis homogenizer. The sample was washed with IPA on a suction filter and 
air-dried with gentle warming to prevent moisture condensation and the development of a horny texture to the gum. The residue from the initial extraction was subjected to further extraction under the same conditions as the first. Routinely, three extractions were carried out, giving three extracts combined together before the step of acidification with $2 \mathrm{M} \mathrm{HCl}$. The gum was isolated as described before by 2-Propanol precipitation

\section{(3). Enzymatic extraction:}

After two extractions of $\beta$-glucan by $1 \mathrm{~N} \mathrm{NaOH}$, the $\mathrm{pH}$ of the combined extracts was adjusted first to 6.5 with hydrochloric acid and calcium chloride added to enhance $\alpha$ - amylase activity. After incubation with $\alpha$-amylase the $\mathrm{pH}$ of the extract was adjusted at 4.5 to precipitate the protein (Bbatty, 1993).

\section{$\underline{\text { 3.1. Identification and Quantitative Determination of isolated } \beta \text { - glucan }}$}

\section{by HPLC:}

High-Performance Liquid Chromatography HPLC [HEWLETT PACKARD HP1047IR, HEWLETTPACKARD HP1047 (pump), HEWLETT PACKARD HP1047 computer monitor] was used for the determination of the extracted $\beta$-glucan by using the method described by Wood et al., (1991).

\section{Physicochemical properties of $\beta$-glucan:}

\subsection{Solubility of $\beta$-glucan samples:}

The solubility of $\beta$-glucan (unpurified) in the native flours (primary solubility) was determined according to the method of Gaosong and Vasanthan (2000). $100 \mathrm{mg}$ of flour was mixed with $10 \mathrm{ml}$ distilled water. The mixture was subjected to continuous shaking for $2 \mathrm{hr}$. at room temperature $(25 ; \mathrm{C})$ followed by centrifugation at $10.000 \mathrm{rpm}$ for $5 \mathrm{~min} \beta$-glucan content 
in an aliquot $(0.1 \mathrm{ml})$ of the supernatant was determined. The solubility was calculated as a percentage of the total $\beta$-glucan content in the flour.

4.2. Foaming property: Whip ability (foaming capacity) and foam stability were measured according to Lin et al. (1974) by dispersing ca. $2.5 \mathrm{~g}$ gum (extracted $\beta$-glucan) in $100 \mathrm{~mL}$ water, whipping for 2 min using a handheld food mixer at high speed $(350 \mathrm{rpm})$ in a stainless steel bowl with straight sides and measuring volumes before and after whipping. Whip ability was reported as the percentage increase in volume due to whipping. Foams were slowly transferred to a $1000 \mathrm{ml}$ graduated cylinder and allowed to set at room temperature $\left(\sim 21^{\circ} \mathrm{C}\right)$ for $2 \mathrm{~h}$. Volume of foam after $2 \mathrm{~h}$ as a percentage of original volume was reported as foam stability

\subsection{Fat absorption capacity:}

Fat absorption capacity was determined according to Bhatty (1986). One gram of sample was mixed with $10 \mathrm{ml}$ corn oil. The mixture was allowed to stand at room temperature for $30 \mathrm{~min}$ and then centrifuged at $1890 \mathrm{xg}$ for $25 \mathrm{~min}$. The free oil was measured and percent oil absorption was calculated.

\subsection{Water hydration capacity (WHC):}

WHC of Extracted $\beta$-glucan: was determined applying the procedure described by Robertson et al., (2000)

\section{Determination of Viscosity:}

The rheological behavior was characterized by preparing aqueous dispersions of $(1.5,3.0,4.5$ and 6.0$) \%(\mathrm{p} / \mathrm{v})$ of the extracted $\beta$-glucans at $80^{\circ}$ $\mathrm{C}(1 \mathrm{~h})$, followed by continuous agitation for $2 \mathrm{~h}$ at room temperature. This procedure guaranteed complete hydration and dispersion without forming 
clumps. The rheological measurements were obtained with a rotational rheometer (Brookfield Engineering Laboratories model RVDV-III Ultra, Stoughton, MA, USA) with concentric cylinders spindle ULA, and the results obtained were processed through the Rheocalc_32(version 2.5) software. The intervals of shear rate: $30,50,70,90 \mathrm{rpm}$ at room temperature $\left(25 \pm 5^{\circ} \mathrm{C}\right)$ were applied, fitted with spindle Lv No. 1. The results were automatically recorded as centipoises (cp.). This method was described by (Limberger-Bayer et al., 2014) but with some modifications was done.

\section{Preparation of Cake:}

White cakes were prepared according to the method described by William (1988) using the following components. Flour 100g, sugar 100g, salt $1.7 \mathrm{~g}$, milk powder $9.1 \mathrm{~g}$, shortening $45.5 \mathrm{~g}$, water $36.4 \mathrm{~g}$, egg whites $68.4 \mathrm{~g}$, baking powder $5.7 \mathrm{~g}$, vanilla $2.3 \mathrm{~g}$. Different cake blends with extracted $\beta$ glucan as partial substitute of fat were formulated.

The physical properties of cakes, height $(\mathrm{cm})$, weight $(\mathrm{gm})$, volume $\left(\mathrm{cm}^{3}\right)$, specific volume $\left(\mathrm{cm}^{3} / \mathrm{g}\right)$ and density $\left(\mathrm{gm} / \mathrm{cm}^{3}\right)$ were measured according to the methods described by AACC (2010). Specific gravity of the batter of cake was measured by method 10-14 (AACC 1983). The $\mathrm{pH}$ of the batter was determined by direct immersion of a $\mathrm{pH}$ electrode in the batter at room temperature $\left(25^{\circ} \mathrm{C}\right.$ ) using a Digital $\mathrm{pH}$ meter (Jenway, Model 3020, Dunmow, Essex, UK).

\section{Statistical analysis:}

The results obtained were analyzed by Analysis of Variance using General Linear Model (GLM) procedure within a package program of 
J. Environ. Sci.

Institute of Environmental Studies and Research - Ain Shams University

Statistical Analysis System (SAS, 1987). Means were separated using Least Significant Difference (LSD) test at a degree of significance $(\mathrm{P} \leq 0.05)$.

\section{RESULTS AND DISCUSSION}

\section{Phytochemical investigations of barley flour and bran:}

The results of these Phytochemical investigations are shown in Table (1). It is clear that, all the constituents of barley bran are higher than whole barley flour itself except total carbohydrates and moisture. But, the content of minerals of bran are lower than flour except $\mathrm{Mg}$ and $\mathrm{K}$. According to Helm and De Francisco (2004) the protein contents in six Brazilian hull-less barley varieties are 12.55 to $15.92 \%$ d.m. and that described by Žilic et al., (2011) for hull-less barley genotypes are 12.59 to $16.91 \%$ d.m. the protein contents determined here are in agreement with them results. Helm and De Francisco (2004) also concluded that crude fat 2.91 to $4.00 \%$, ash 1.51 to $2.27 \%$ and crude fiber 5.95 to $7.12 \%$ and the result of the present study fall within the ranges reported by these investigators. Concerning the barley bran, Bhatty (1993 and 1995) reported that, the protein content of barley bran ranged between $13.60-18.70 \%$, fat 2.70 to $3.8 \%$ and the starch 51.0 to $57.1 \%$.

Mangan et al., (2015) stated that among 33 Tibetan barley grain samples the Fe and $\mathrm{Zn}$ contents are: $29-65$ and 20-55 $\mathrm{mg} \mathrm{kg}^{-1}$ respectively. Our results are in agreement with these results, but disagreement with Kan, (2015) who reported that barley cultivars from Turkey have $\mathrm{K}$ (635), $\mathrm{Ca}$ (48.7), $\mathrm{Mg}$ (166.7) and $\mathrm{Na}(12.4) \mathrm{gm} / 100 \mathrm{~g}$. This might be due to the variation in genetic 
material, as well as, agronomic and environmental conditions experienced by the tested material.

Table (1): Chemical composition of raw material of barley flour and barley bran (dry weight basis)

\begin{tabular}{|l|c|c|}
\hline \multicolumn{1}{|c|}{ Constituents } & Barley flour & Barley bran \\
\hline Protein (\%) & 14.69 & 15.96 \\
Ash (\%) & 2.20 & 2.65 \\
Ether Extract (\%) & 2.45 & 3.30 \\
Crude Fiber (\%) & 3.83 & 6.35 \\
Total carbohydrates* & 76.83 & 71.83 \\
\hline Minerals contents & & \\
( mg/100g sample) & 6.58 & 5.89 \\
Fe & 17.23 & 6.75 \\
$\mathrm{Ca}$ & 6.38 & 4.64 \\
$\mathrm{Zn}$ & 307.8 & 495.8 \\
$\mathrm{Mg}$ & 222.6 & 232.1 \\
$\mathrm{~K}$ & 1001.0 & 898.6 \\
$\mathrm{Na}$ & & \\
\hline
\end{tabular}

*Calculated by difference. Moisture content for barley flour 10.20 and for barley bran 10.5.

The total dietary fibre, total $\beta$-glucan of raw materials are listed in Table (2). It is obvious that the values of $\beta$-glucan and dietary fiber of barley bran are higher than barley flour. These results are in good agreement with those of previous investigators (Holtekjolen et al., 2006; Izydorczyk et al., 2003; Bhatty, 1999; Zheng et al., 2011 and Sudha et al., 2007). 
Table (2): Total, Soluble and Insoluble dietary fibre and $\beta$-glucan of used raw materials (dry weight basis).

\begin{tabular}{|l|l|l|l|l|l|l|}
\hline \multirow{2}{*}{ Sample } & \multicolumn{3}{|c|}{ Dietary fibre \% } & \multicolumn{3}{c|}{$\beta$-glucan } \\
\cline { 2 - 7 } & Total & Soluble & Insoluble & Total & Soluble & Insoluble \\
\hline \hline Barley flour & 12.86 & 6.13 & 6.73 & 4.81 & 3.68 & 1.13 \\
\hline Barley bran & 16.56 & 7.93 & 8.63 & 7.36 & 5.65 & 1.71 \\
\hline
\end{tabular}

In earlier studies the variations in TDF, SDF and IDF contents of barley flour have been reported to range from 7.5 to $16.8 \%, 5.6$ to $6.4 \%$, and 1.9 to 10.4\%, respectively in barley (Helm and De Francisco, 2004; Vasanthan et al., 2002). The results obtained in the present study are similar to these values.

\section{Isolation and characterization of $\beta$-glucan:}

$\beta$-Glucan was extracted from barley flour (whole) and barley bran by the methods described before (cf. the experimental part). The yield of $\beta$-glucan from the three methods and its recovery percentage values are listed in Table (3). The yield of gum (extracted $\beta$-glucan) product represents the weight of gum obtained from $100 \mathrm{~g}$ of flour.

The results of table (3) indicate that there is no significant difference ( $p \leq$ 0.05 ) between the extracted values of $\beta$-glucan from flour by methods 2,3 a significant increase in the value of $\beta$-glucan from b-bran in method 3 . Efficiency of $\beta$-glucan extraction was determined by dividing, $\mathrm{g} \beta$-glucan in $100 \mathrm{~g}$ fraction by $\mathrm{g} \beta$-glucan in $100 \mathrm{~g}$ bran or flour. In this investigation the recovery percentage was significantly different at $p \leq 0.05$ for extraction value from b-bran and b-flour and high values from b-bran because $\beta$-glucans 
are usually concentrated in the outer layers, internal aleurone and subaleurone endosperm cells walls (Demirbas, 2005 and Holtekjolen et al., 2006). Lower efficiency by hot water extraction method was observed, also by Symnons and Brennan, (2004) who ascribed this to the $\beta$-glucan cleavage by $\beta$ glucanase enzyme. The recovery values ranged from 58.18 to $79.35 \%$, which are lower than those reported by Vizhi and Many, (2012). Previous studies showed a recovery of 60-76\% $\beta$-d-glucan (Ahmad et al., 2009). The higher recovery in enzymatic process in the present study may be attributed to a prior treatment with ethanol and the use of appropriate enzymes that reduce the intermolecular association of $\beta$-d-glucan with other components of oat that resulted in high extractability of $\beta$-d glucan. Similar observations were recorded by Xu et al., (2007).

Table (3): Percentage of Recovery of $\beta$-glucan content (\%)

\begin{tabular}{|c|c|c|c|c|c|c|}
\hline $\begin{array}{l}\text { Treatments } \\
\text { (methods) }\end{array}$ & $\begin{array}{c}\text { Yield- } \\
\text { extracted } \beta \text { - } \\
\text { glucan } \% \\
\text { from bran }\end{array}$ & $\begin{array}{c}\beta \text {-glucan } \\
\text { content (\%) in } \\
\text { barley bran }\end{array}$ & $\begin{array}{l}\text { Percentage of } \\
\text { Recovery (\%) }\end{array}$ & $\begin{array}{l}\text { Yield-extracted } \\
\beta \text {-glucan } \% \\
\text { from flour }\end{array}$ & $\begin{array}{c}\beta \text {-glucan } \\
\text { content (\%) in } \\
\text { barley flour }\end{array}$ & $\begin{array}{l}\text { Percentage of } \\
\text { Recovery (\%) }\end{array}$ \\
\hline $\begin{array}{c}\text { (l)Water } \\
\text { Extraction }\end{array}$ & $4.68 \pm 0.005^{c}$ & & $63.59 \pm 0.7^{c}$ & $2.79 \pm 0.1^{\mathrm{b}}$ & & $58.18 \pm 1.7^{b}$ \\
\hline $\begin{array}{c}\text { (2)water- } \\
\text { Alkaline } \\
\text { Extraction }\end{array}$ & $5.41 \pm 0.005^{b}$ & $7.36 \pm 0.05$ & $73.51 \pm 0.7^{b}$ & $3.05 \pm 0.15^{\AA}$ & $4.81 \pm 0.1$ & $68.33 \pm 2.5^{\mathrm{a}}$ \\
\hline $\begin{array}{l}\text { (3)Alkalin } \\
\text { Enzymatic } \\
\text { Extraction }\end{array}$ & $5.84 \pm 0.005^{\mathrm{a}}$ & & $79.35 \pm 0.7^{\mathrm{a}}$ & $3.44 \pm 0.06^{\mathrm{a}}$ & & $71.43 \pm 1.0^{\mathrm{a}}$ \\
\hline
\end{tabular}

Means in the same column with different letters are significantly different $(p \leq 0.05)$. Means \pm SE (stander error)

*For the next part of the study the water-alkaline extracted fraction from methd (2) was selected (without pre-treatment step), as being the most stable, safety and economical $\beta$-glucan containing fraction, for inclusion into bakery products. 
The extracted $\beta$-d-glucan was quantified and identified by HPLC analysis which gave retention time $10.1 \mathrm{~min}, \beta$-glucan recovery value $(75.229 \%)$ and pentosan $(3.61 \%)$ was detected. The extracted $\beta$-d-glucan sample was subjected to complete analysis. The results are listed in Table (4).

Table (4): Proximate analysis of extracted $\beta$-glucan gum pellet

\begin{tabular}{|l|c|}
\hline Constituents & (g/100g) \\
\hline Moisture & 9.25 \\
Protein & 4.15 \\
Ash & 1.67 \\
Ether extract & 2.27 \\
Crude Fiber & 0.53 \\
Starch & 2.30 \\
pentosan & 3.61 \\
( -glucan) & 76.22 \\
Total Dietary Fiber & 82.15 \\
\hline Minerals contents ( mg/100g sample ) & \\
Ca & 5.85 \\
K & 97.43 \\
Na & 812.55 \\
Mg & 473.5 \\
Zn & 4.29 \\
Fe & 6.04 \\
\hline
\end{tabular}

The above results are in good agreement with those reported by Ahmad et al., (2010) and Burkus and Temelli (2005).

\section{Functional properties of extracted $\beta$-glucan gum pellets:}

Solubility, Water-hydration capacity (WHC), Fat absorption capacity (FAC) and Foaming capacity of $\beta$-glucan gum was investigated and listed in Table (5). 
Table (5): Functional properties of beta-glucan pellet

\begin{tabular}{|l|l|}
\hline Property & g/ 100g (\%) \\
\hline \hline Solubility & 53.11 \\
Water-hydration capacity WHC & 315 \\
Fat absorption capacity FAC & 365 \\
Foaming capacity & 155 \\
Foam stability & 60.6 \\
\hline
\end{tabular}

The results obtained in our study (c.f. Table 5), are comparable with those obtained by previous investigators (Gaosong and Vasanthan 2000; Vizhi and Many 2012 and Bae et al., 2009).

Foaming capacity and stability are the two important factors when the beta-glucan is used as a functional ingredient Vizhi and Many (2012). High foaming capacity and stability show more desirable characteristics in the preparation of cakes and batter. Proteins in the gum obtained at low $\mathrm{pH} / \mathrm{low}$ temperature conditions may be expected to have better functionality. Thus, proteins must make a significant contribution to whippability (Foaming capacity) and foam stability.

The effect of different concentrations of extracted $\beta$-glucan and different shear rates on viscosity of extracted $\beta$-glucan were determined (c.f. Table 6). Examination of the values obtained reveals that the viscosity is increased with increasing the concentration of $\beta$-glucan. On the other hand, increasing the shear rates caused an observed decrease in $\beta$-glucan viscosity. At concentrations $(>0.2 \%)$ the high molecular weight $\beta$-glucan molecules start to entangle and form viscus and pseudo-plastic behavior solutions (Doublier and wood 1995). 
Table (6): The effect of different concentrations of extracted $\beta$-glucan and different shear rates on viscosity of extracted $\beta$-glucan.

\begin{tabular}{|c|c|c|c|c|}
\hline \multirow{2}{*}{ Shear rates } & \multicolumn{4}{|c|}{ Concentrations of $\boldsymbol{\beta}$-glucan \% } \\
\cline { 2 - 5 } & $\mathbf{1 . 5}$ & $\mathbf{3 . 0}$ & $\mathbf{4 . 5}$ & $\mathbf{6 . 0}$ \\
\hline \hline 30 & 180.11 & 195.41 & 215.56 & 235.18 \\
\hline 50 & 135.65 & 165.18 & 186.45 & 204.17 \\
\hline 70 & 96.88 & 123.56 & 146.95 & 186.87 \\
\hline 90 & 73.81 & 101.15 & 125.36 & 165.22 \\
\hline
\end{tabular}

\section{The use of extracted $\beta$-glucan as fat replacer in cake production:}

After physical properties and chemical studies of extracted $\beta$-glucan, it was of interest to the authors to use it as partial substitute of fat in making healthy cakes. Low calories white layer cake blends were prepared with a study of their physical properties (batter and cake) and chemical composition. The results obtained are listed in Tables 7 and 8.

It is clear from the data of Table (7) that there are significant differences between $50 \%$ substitution and control, $75 \%$ substitution at $(p \leq 0.05) .50 \%$ Substitution gave higher values than the others in height, volume, weight and specific volume but gives lower values in specific gravity, $\mathrm{pH}$ and density. This indicates that $50 \%$ substitution of fat by $\beta$-glucan gives a cake of high quality. 
Table (7): Batter characteristics as influenced by fat replacer ( $\beta$ - glucan) levels and physical properties of low calories cake prepared with different fat replacer levels.

\begin{tabular}{|c|c|c|c|c|}
\hline \multirow{2}{*}{ Property } & \multicolumn{3}{|c|}{ Replacer level } & \multirow{2}{*}{ L.S.D 0.05} \\
\hline & 0\% (control) & $50 \%$ & $75 \%$ & \\
\hline $\begin{array}{l}\text { Batters } \\
\text { Specific gravity } \\
\text { pH }\end{array}$ & $\begin{array}{l}0.95^{\mathrm{a}} \\
7.11^{\mathrm{a}}\end{array}$ & $\begin{array}{c}0.92^{\mathrm{b}} \\
6.86 .5^{\mathrm{a}}\end{array}$ & $\begin{array}{l}0.94^{\mathrm{a}} \\
6.73^{\mathrm{c}}\end{array}$ & $\begin{array}{l}0.1 \\
0.1\end{array}$ \\
\hline $\begin{array}{l}\text { Cakes } \\
\text { Height }(\mathrm{cm}) \\
\text { Volume }\left(\mathrm{cm}^{3}\right) \\
\text { Weight }(\mathrm{gm}) \\
\text { Specific volume } \\
(\mathrm{cm} / \mathrm{gm}) \\
\text { Density }\left(\mathrm{gm} / \mathrm{cm}^{3}\right)\end{array}$ & $\begin{array}{c}5.0^{\mathrm{c}} \\
420^{\mathrm{c}} \\
160.76^{\mathrm{c}} \\
\\
2.61^{\mathrm{c}} \\
0.38^{\mathrm{a}}\end{array}$ & $\begin{array}{c}6.5^{\mathrm{a}} \\
470^{\mathrm{a}} \\
168.7^{\mathrm{a}} \\
\\
2.79^{\mathrm{a}} \\
0.35^{\mathrm{b}}\end{array}$ & $\begin{array}{c}5.5^{\mathrm{b}} \\
440^{\mathrm{b}} \\
164.69^{\mathrm{b}} \\
\\
2.67^{\mathrm{b}} \\
0.37^{\mathrm{a}}\end{array}$ & $\begin{array}{l}0.32 \\
8.00 \\
3.13 \\
0.01 \\
0.01\end{array}$ \\
\hline
\end{tabular}

Means in the same row with different letters are significantly different $(p \leq 0.05)$ for each effect.

L.S. $\mathrm{D}_{0.05}$ least significant differences at $(p \leq 0.05)$

It is clear from the data of Table (8) that there was no significant difference $(p \leq 0.05)$ in crude protein. But there are high significant differences in total fat and total calories, both decreasing by increasing the level of $\beta$-glucan. 
Table (8): Chemical composition of low calorie white layers cakes prepared with different fat replacer levels by $\beta$ - glucan (on dry weight basis).

\begin{tabular}{|l|c|c|c|c|}
\hline \multirow{2}{*}{ Constituents } & \multicolumn{3}{|c|}{ Replacer level } & \multirow{2}{*}{ L.S.D. $\mathbf{D}_{\mathbf{0 . 0 5}}$} \\
\cline { 2 - 4 } & $\mathbf{0 \%}($ Control) & $\mathbf{5 0 \%}$ & $\mathbf{7 5 \%}$ & 0.41 \\
\hline \hline Crude protein & $8.87^{\mathbf{a}}$ & $8.92^{\mathbf{a}}$ & $8.96^{\mathbf{a}}$ & 1.06 \\
Total fat & $20.73^{\mathbf{a}}$ & $14.60^{\mathbf{b}}$ & $10.66^{\mathbf{c}}$ & 0.07 \\
Total ash & $1.78^{\mathbf{c}}$ & $1.91^{\mathbf{b}}$ & $2.13^{\mathbf{a}}$ & \\
*Total carbohydrate & & & & 2.13 \\
Moisture & $68.62^{\mathbf{c}}$ & $74.57^{\mathbf{b}}$ & $78.25^{\mathbf{a}}$ & 1.20 \\
**Total Calories & $23.24^{\mathbf{b a}}$ & $24.82^{\mathbf{a}}$ & $24.31^{\mathbf{a}}$ & 11.20 \\
& $496.53^{\mathbf{a}}$ & $465.36^{\mathbf{b}}$ & $444.78^{\mathbf{c}}$ & 11 \\
\hline
\end{tabular}

*Calculated by difference. $* *$ calculated

Means in the same row with different letters are significantly different $(p \leq 0.05)$ for each effect

\section{CONCLUSION}

The results of this study show clearly that the use of barley and beta glucan extracted from it as naturally functional ingredients gave food products of acceptable nutrition value. In addition, the wide range of therapeutic uses of these naturally occurring components might represent another benefit for using them in food.

\section{REFERENCES}

A.A.C.C. (2010): American Association of Cereal Chemists International Approved Methods. $11^{\text {th }}$ ed. St. Paul, Minnesota: AACC International.

A.A.C.C. (1983): AACC Approved Methods, 8th Ed., American Association of Cereal Chemists, St. Paul, MN. 
Ames, N.; Rhymer, C.; Rossnagel, B.; Therrien, M.; Ryland, D.; Dua, S. and Ross, K. (2006): Utilization of diverse hulless barley properties to maximize food product quality. Cereal Foods World. 41: 23-28.

Ahmad, A.; Anjum, F. M.; Zahoor, T.; Nawaz, H. and Din, A. (2009): Physicochemical and functional properties of barley b-glucan as affected by different extraction procedures Food Sci. Technol. 44: 181-187.

Ahmada, A.; Anjumb, F. M.; Zahoorb, T.; Nawazc, H. and Ahmed Z. (2010): Extraction and characterization of $\beta$-d-glucan from oat for industrial utilization. International Journal of Biological Macromolecules 46: 304-309.

Anonymous, (2006): Barley facts-FDA health claims. http://www.barleyfoods.org/barleyfacts-fda.pdf (accessed April 18, 2007).

Bae, In Y.; Lee S.; Mi Kim, S. and Gyu Le, H. (2009): Effect of partially hydrolyzed oat b-glucan on the weight gain and lipid profile of mice. Food Hydrocolloids 23: 2016-2021

Benito, O.; Alonso, E. and Lucas, S. (2009): Study of the effect of different pretreatments on the performance of the extraction of $\beta$-glucan from barley. Chemical Engineering Transaction 17: 927-932.

Bhatty, R. S. (1986): Physiochemical and functional (bread making) properties of hull less barley fractions. Cereal Chem. 69 (5): 469 471.

Bhatty, R. S. (1993): Extraction and enrichment of $(1 \rightarrow 3)(1 \rightarrow 4)-\beta-d-$ glucan from barley and oat brans. Cereal Chemistry 70: 73-77.

Bhatty, R. S. (1995): Laboratory and pilot plant extraction and purification of $\beta$-glucans from hull-less barley and oat bran. Journal of Cereal Science, 22: 163-170.

Bhatty, R.S. (1999): $\beta$-Glucan and flour yield of hull-less barley. Cereal Chem., 76, 314-315.

Burkus, Z. and Temelli, F. (1998): Effect of extraction conditions on yield, composition, and viscosity stability of barley $\beta$-glucan gum, Cereal Chemistry, 75: 805-809. 
Burkus, Z. and Temelli, F. (2005): "Rheological properties of barley [beta]glucan."Carbohydrate Polymers 59(4): 459-465.

Carr, J. M.; Glatter, S.; Jeraci, J. L., and Lewis, B. A. (1990): Enzymic determination of $\beta$-glucan in cereal based food products. Cereal Chem. 67: 226-229.

Demirbas A. (2005): $\beta$-Glucan and mineral nutrient contents of cereals grown in Turkey. Food Chemistry, 90: 773-777.

Doublier, J. - L. and Wood, P. J. (1995): Rheological properties of aqueous solutions of (1-3) (1-4)- $\beta$-D- glucan from oats (Avena Sativa L.). Cereal Chemistry 72: $335-340$.

Gaosong, J. and Vasanthan, T. (2000): Effect of extrusion cooking on the primary structure and water solubility of $\beta$-glcans from regular and waxy barley. Cereal Chem. 77(3): 396 - 400.

HGCA (2003): Recommended Lists for cereals and oilseeds. Home-Grown Cereals Authority, London, UK.

Helm, C. V.; A. DE FRANCISCO (2004): Chemical characterization of brazilian hulless barley varieties, flour fractionation, and protein concentration. Sci. Agric. (Piracicaba, Braz.) 61, 593-597.

Holtekjolen, A.K.; Uhlen, A.K.; Brathen, E.S.; Sahlstrom, S. and Knutsen, S.H. (2006): Contents of starch and non-starch polysaccharides in barley varieties of different origin. Food Chemistry, 94: 348-358.

Izydorczyk, M. S.; Jacobs, M.; Dexter, J. E. (2003): Distribution and structural variation of non starch polysaccharides in milling fractions of hull-less barley with variable amylose content. Cereal Chem. 80: 645-653.

Jackson, M. (1976): "Soil Chemical Analysis". Prentice-Hall Inc, Englewood Cliffs. N.J pp: 123-25.

Limberger-Bayer, V. M.; de Francisco, A.; Chan, A.; Oro, T.; Ogliari, P. J. and Barreto, P. L.M. (2014): Barley $\beta$-glucans extraction and partial characterization. Food Chemistry 154: 84-89. 
Lin, M. J. Y., and Humbert, E. S. (1974): Certain functional properties of sunflower meal products. Journal of Food Science, 39: 368-370.

Mahdi, G. S.; Abdal, M.; Behera, B. C.; Verma, N.; Sonone, A. and Makhija, U. (2008): Barley is a healthful food: a review. Electron J Environ Agric Food Chem.; 7: 2686 - 94.

Mangan, B.-N.; Hui, L.; Lashari, M. S.; Shah, A. N.; Licao, C. and Weining, S. (2015): Nutritional characteristics and starch properties of Tibetan barley. Int. J. Agric. Pol. Res. Vol. 3 (7): 293 - 299.

Prsoky, L.; Asp, N. G.; Furda, I.; Vries, J. W.; Schweizer, T. F. and Harland, B. H. (1985): Determination of total dietary fiber in food products: Collaborative study. Assoc. off Anal Chem. 2(4): 677679.

Prsoky, L.; Asp, N. G.; Schweizer, T. F.; Devyies, J. W. and Furda, I. (1988): Determination of insoluble, soluble and total dietary fibre in food and food products: inter laboratory study. J. Assoc. of Anal. Chem. 2(4): 677-679.

Quinde-Axtell, Z. and Baik, B. K. (2006): Phenolic compounds of barley grain and their implication in food products discoloration. J. Agric. Food Chem 54: 9978 - 9984.

Robertson, J. A.; Monredon, D. F.; Dysler, P.; Guillon, F.; Amado, R.; and Thibault, J. F. (2000): Hydration properties of dietary fibre and resistant starch: a European Collaborative study. Lebensm-Wiss Technol. 33: 72-79.

SAS (1987): SAS propriety software. Statistical Analysis Institute Inc., Cary, North Carolina, USA.

Symons, L. J. and Brennan, C. S. (2004a): The effect of barley $\beta$-glucan fibre fractions on starch gelatinization and pasting characteristics. J. Food Science (In Press). Vol. 69, (4): 257-261.

Temelli, F. (1997): Extraction and Functional Properties of Barley b-Glucan as Affected by Temperature and $\mathrm{pH}$ Journal of Food Science, 62 (6): 1194 - 1201.

USDA (2015): "National School Lunch Program Fact Sheet." 
Vizhi, V. .; Many, J. N. (2012): Study on Estimation, Extraction and Analysis of Barley Beta-glucan. International Journal of Science and Research (IJSR) 3 (10): 1480 - 1484.

William, J. S. (1988): Practical Baking, Revised, Third Edition The Avi Publishing Company, Inc. west port, Connecticut.pp.97- 99.

Wood, P. J.; Paton, D. and Siddiqui, I. R. (1977): Determination of $\beta$-glucan in oats and barley. Cereal Chemistry, 54: 524-533.

Wood, P. J.; Siddiqui, I. R. and Paton, D. (1978): Extraction of high viscosity gums from Oat. Cereal Chem. 55(6):1038-1049.

Wood, P. J.; Weisz, J.; Fedec, P. and Burrows, V. D. (1989): Large-scale preparation and properties of oat fractions enriched in (1-3) (1-4) - $\beta$-D-glucan. Cereal Chem. 66:97-103.

Wood, P. J.; Weisz, j. and Blackwell, B. A. (1991): Molecular Characterization of Cereal $\beta$-D-Glucans. Structural analysis of oat $\beta$-D- Glucan and rapid structural evaluation of $\beta$-D-Glucans from different sources by High- Performance Liquid Chromatography of oligosaccharides released by lichenase. Cereal Chem. 68(1): 31-39.

Xu, F.; Sun, J. X.; Geng, Z. C.; Liu, C. F.; Ren, J. L.; Sun, R. C.; Fowler, d. P. and Baird, M. S. (2007): Comparative study of water-soluble and alkali-soluble hemicelluloses from perennial ryegrass leaves (Lolium peree). Carbohydrate Polymers 67: 56-65.

Zheng, X.; Li, L. and Wang, Q. (2011): Distribution and Molecular Characterization of $\beta$-Glucans from Hull-Less Barley Bran, Shorts and Flour. Int. J. Mol. Sci. 12:1563-1574. 


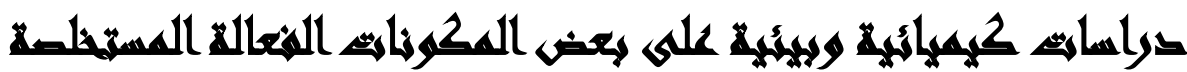

\section{هن الثعير}

\section{[0]}

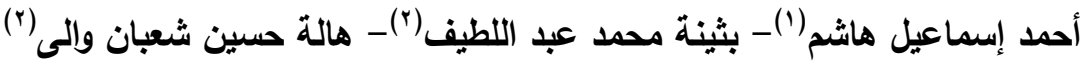

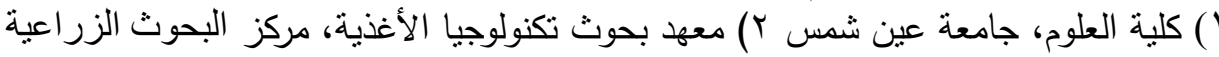

\section{المستخليس}

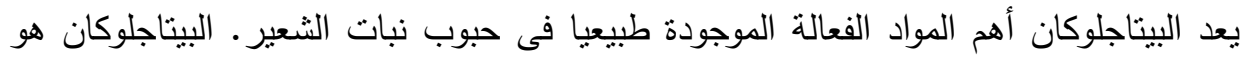

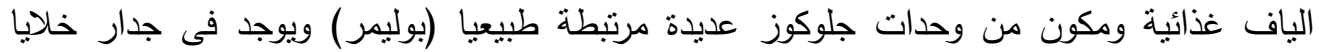

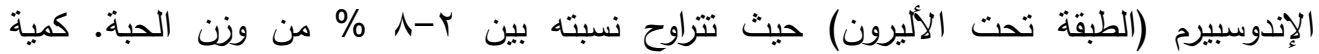

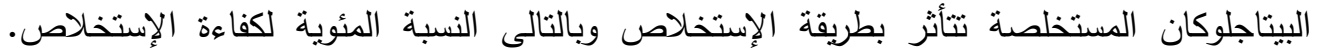

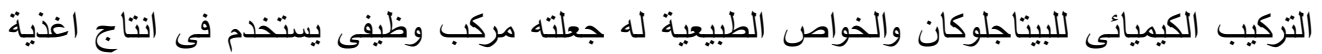
صحية. تتشأ فائدة البيتاجلوكان الصحية من لذوجته العالية وكونه من الألباف الغذائية القابلة للذوبان.

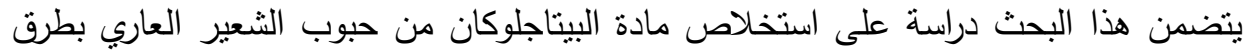

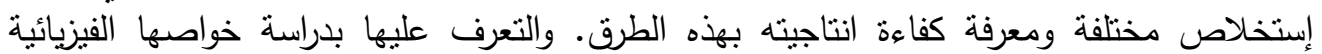

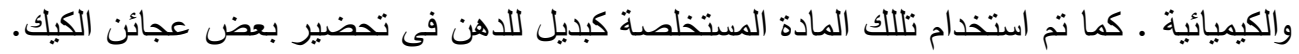

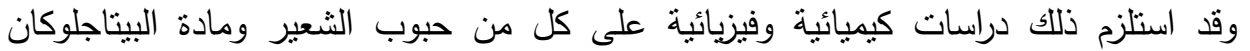

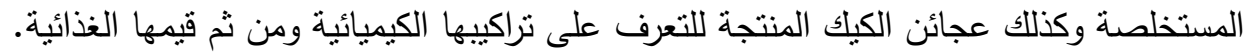
الكلمات الادالة: بيتاجلوكان، حبوب الثعير ، عجائن الكيك، الخواص الثرائ الفيزيائية والكيميائية. 